\title{
Criminal or administrative law to protect the environment? Evidence from Western Europe
}

Citation for published version (APA):

Faure, M. G., \& Svatikova, K. (2012). Criminal or administrative law to protect the environment? Evidence from Western Europe. Journal of Environmental Law, 24(2), 253-286. https://doi.org/10.1093/jel/eqs005

Document status and date:

Published: 01/01/2012

DOI:

10.1093/jel/eqs005

Document Version:

Publisher's PDF, also known as Version of record

Document license:

Taverne

Please check the document version of this publication:

- A submitted manuscript is the version of the article upon submission and before peer-review. There can be important differences between the submitted version and the official published version of record.

People interested in the research are advised to contact the author for the final version of the publication, or visit the DOI to the publisher's website.

- The final author version and the galley proof are versions of the publication after peer review.

- The final published version features the final layout of the paper including the volume, issue and page numbers.

Link to publication

\footnotetext{
General rights rights.

- You may freely distribute the URL identifying the publication in the public portal. please follow below link for the End User Agreement:

www.umlib.nl/taverne-license

Take down policy

If you believe that this document breaches copyright please contact us at:

repository@maastrichtuniversity.nl

providing details and we will investigate your claim.
}

Copyright and moral rights for the publications made accessible in the public portal are retained by the authors and/or other copyright owners and it is a condition of accessing publications that users recognise and abide by the legal requirements associated with these

- Users may download and print one copy of any publication from the public portal for the purpose of private study or research.

- You may not further distribute the material or use it for any profit-making activity or commercial gain

If the publication is distributed under the terms of Article $25 \mathrm{fa}$ of the Dutch Copyright Act, indicated by the "Taverne" license above, 
Journal of Environmental Law 24:2 @ The Author 2012. Published by Oxford University Press. All rights reserved. For Permissions, please email: journals.permissions@oup.com doi:10.1093/jel/eqs005 Advance Access published on 2 May 2012

\title{
Criminal or Administrative Law to Protect the Environment? Evidence from Western Europe
}

\author{
Michael G. Faure and Katarina Svatikova*
}

\begin{abstract}
This article studies the scope of criminal and administrative law enforcement of environmental violations in four Western European jurisdictions. The Flemish Region and the United Kingdom have, until mid-2009, largely relied only on criminal sanctioning while administrative sanctions, which have also been in use since mid-2009, have already been widely used in the Netherlands and Germany. This article considers whether, given a fixed budget for the relevant national environment agency, single (criminal) or multiple (criminal and administrative) enforcement instruments are adequate to induce compliance. The fact that administrative proceedings are less strict and more informal than criminal proceedings suggests that the imposition of administrative sanctions is a relatively cheaper alternative. Therefore, in case of environmental violations, it is cost-effective to complement criminal law enforcement by administrative law rather than to allow for a single (criminal) sanctioning instrument. Complementary use of these two instruments might lead to additional deterrence. Data is presented to illustrate this argument.
\end{abstract}

* Michael Faure, Rotterdam Institute of Law \& Economics (RILE), Erasmus University Rotterdam, Postbus 1738, 3000 DR Rotterdam, The Netherlands (michael.faure@maastrichtuniversity.nl); METRO Institute, Faculty of Law, University of Maastricht (www.personeel.unimaas.nl/ michael.faure), The Netherlands. Katarina Svatikova, Rotterdam Institute of Law \& Economics (RILE), Erasmus University Rotterdam, currently working for ECORYS B.V., Watermanweg 44, 3067 GG, Rotterdam, The Netherlands (katarina.svatikova@ecorys.com). The authors would like to thank the participants of the workshop 'Beyond the Economics of Crime' in Heidelberg, March 2009, particularly John List and Daan van Soest. We are equally grateful to the participants at the meeting of the European Association of Law and Economics (September 2009). Special thanks to Sandra Rousseau and Carole Billiet for their useful comments, as well as to John Klick, Vincent Buskens and to two anonymous referees of this journal. The usual disclaimers apply. 
Keywords: administrative sanctions, administrative fines, criminal sanctions, enforcement

\section{Introduction}

Recent Law and Economics scholarship has paid attention to the question of why criminal law is used at all for certain harmful activities. ${ }^{1}$ On the basis of this literature, criteria have been developed indicating when, from an economic perspective, criminalisation would be warranted. These criteria point to the use of the criminal law only under limited circumstances because this instrument is costly for society (in terms of relatively high enforcement costs) as well as for the offender (in terms of relatively severe, legal and non-legal, sanctions). Thus, it could be implied that only for certain, usually serious violations, should criminal sanctions be applied. These insights have been applied to environmental law as well. ${ }^{2}$

Even though Law and Economics recommends a relatively modest role for criminal law to protect the environment, in practice (until recently), in some European jurisdictions, such as the Flemish Region and the UK, one could still observe a large reliance on the criminal law, at least in written legislation. However, Law and Economics scholarship has pointed to the fact that this leads de facto to many cases where the criminal law is effectively not applied at all as a result of which no sanctions follow. This results in underdeterrence. ${ }^{3}$ Despite this drawback of criminal law enforcement, the European trend remains intent on its use as the primary enforcement instrument. After various unsuccessful attempts, Europe promulgated Directive 2008/99/EC of 19 November 2008 on the protection of the environment through criminal law. ${ }^{4}$ This Directive harmonises and strengthens the role of criminal law in environmental protection, obliging the Member States to enforce a large number of environmental directives through criminal law. The type and the level of sanctions are at the discretion of the Member States with one condition: the

1 Roger Bowles, Michael G Faure and Nuno Garoupa. 'The Scope of Criminal Law and Criminal Sanctions: An Economic View and Policy Implications' (2008) 35 Journal of Law and Society 389; Anthony Ogus, 'Enforcing Regulation: Do We Need the Criminal Law?' in Hans Sjogren and Goran Skogh (eds), New Perspectives on Economic Crime (Edward Elgar 2004) 42.

2 Anthony Ogus and Carolyn Abbot. 'Sanctions for Pollution: Do We Have the Right Regime?' (2002) 14 Journal of Environmental Law 283.

3 ibid.

4 Directive 2008/99/EC of the European Parliament and of the Council of 19 November 2008 on the protection of the environment through criminal law (Criminal Law Directive) [2008] OJ L328/28. 
sanctions implemented into national laws have to be effective, dissuasive and proportional. ${ }^{5}$ This is in sharp contrast to the trend in several European countries, where the use of administrative fines is gaining more and more importance. This opens up the interesting question of whether relying so strongly on criminal law (as the EU Directive does) is effective and proportional.

Therefore, this article studies the enforcement of environmental violations in the Flemish Region, the Netherlands, Germany and England and Wales, particularly in so far as the divide between administrative and criminal law enforcement is concerned. The degree to which criminal sanctioning is used will be investigated and whether this is adequate to enforce environmental violations considered. Further consideration is given to whether an additional instrument, such as administrative fines, is necessary for a range of violations that do not merit criminal prosecution but merit enforcement. The reason for choosing these jurisdictions is that the Flemish Region and the UK, until mid-2009, largely relied on criminal sanctions, whereas Germany and the Netherlands used (and continue to use) administrative sanctions as the main enforcement tool for environmental regulations. Since each system is different, we derive more insights by looking at four jurisdictions rather than only two. As we have data for England and Wales only, we will be disregarding Scotland in this article. In 2008-09, administrative fines were introduced both in the Flemish Region and the UK. By administrative law enforcement, we mean that the environmental agency itself has the power to impose an administrative fine (Germany) or an administrative order which results in penalisation through a fine if it is not complied with (the Netherlands). The latter could be seen as a quasi-administrative fine, even though the primary purpose is to stop the harmful activity. Neither in the Flemish Region nor in the UK until recently, did the environmental agency possess the power to impose an administrative fine (with a few exceptions). ${ }^{6}$

The main difference between an administrative and criminal sanctioning system is that administrative fines are easier to administer and impose (and are therefore presumed less costly) than criminal sanctions because of the more complicated criminal procedure. ${ }^{7}$ We want to examine whether, given a fixed budget for environmental agencies, a single (criminal) or multiple (criminal and administrative) enforcement instruments are more effective to induce

5 There is still significant discussion at EU and Member State level about what exactly this means. For details see Michael G Faure, 'Effective, Proportional and Dissuasive Penalties in the Implementation of the Environmental Crime and Ship Source Pollution Directives: Questions and Challenges' (2010) 19 European Energy and Environmental Law Review 256.

6 Our main focus in the article is on administrative monetary penalties (fines) since these are similar to criminal fines in the sense that they are punitive and monetary. However, we also have some data on other (non-monetary) administrative penalties (such as notices). We also discuss these so as to cover administrative sanctioning as a whole.

7 Michael G Faure, Anthony Ogus and Niels Philipsen, 'Curbing Consumer Financial Losses: The Economics of Regulatory Enforcement' (2009) 31 Law \& Policy 161. 
compliance. The fact that administrative proceedings tend to be less strict and more informal than criminal proceedings, and the environmental agency itself imposes the administrative sanction (no further step to the public prosecutor) suggests that the imposition of administrative sanctions, including an administrative fine, is relatively cheaper. Therefore, the working hypothesis is that, in case of environmental violations, it is cost-effective to complement criminal law enforcement with administrative law enforcement that would allow for the imposition of administrative fines, rather than only allowing for a single (criminal) sanctioning instrument.

Complementary use of these two instruments might lead to additional deterrence. Available empirical data will illustrate our argument. Since the data derives from different sources and is rather limited, it does not allow us to engage in a thorough comparative empirical study of enforcement practices in the four jurisdictions. Nonetheless, despite the limitations of the data, it is still important to work with what we currently have rather than wait until more robust statistics become available. For policy relevant research, timely analysis with indicative conclusions, even if based on less precise data is important, since policies might become outdated by the time complete enforcement statistics become available, if at all. The stylised facts indicate that the number of criminal cases dismissed by the prosecutor is, on average, relatively high vis-à-vis the number of environmental violations. Administrative sanctioning might be able to deal with a part of these dismissals at a relatively low cost.

The article is structured as follows: first we briefly sketch the theoretical framework on enforcement of environmental law, mainly paying attention to the choice between enforcement through administrative or criminal law (Section 2); next we sketch experiences with both enforcement systems in four countries (Section 3) and we engage in a critical comparative analysis (Section 4). Our concluding remarks focus on some of the consequences of our findings for enforcement theory and current EU policy.

\section{Theoretical Framework}

\subsection{Optimal Enforcement: Inducing Compliance}

The economic approach to law enforcement goes back to the seminal paper by Becker who, using a cost-benefit model, argues that a violation can be deterred when the expected costs of a violation are higher than the expected benefits. ${ }^{8}$

8 Even though this Becker model is still often used as a starting point for the economic analysis of crime policy, there are of course also other approaches (see eg John Braithwaite, Crime, Shame and Reintegration (CUP 1989)) holding that non-compliance may not be an intentional decision but for example the result of ignorance. We address the importance of those alternative explanations below in Section 4. 
Traditionally, the Becker hypothesis has been applied mainly to the incentives created by the criminal justice system. For the purposes of this article, we presume that the Becker model can be applied to incentives provided by the administrative sanctioning system. The expected costs of a violation refer to the expected sanction (ES) a violator might face when caught. The ES is determined by multiplying the probability of detection and sanctioning $(p)$ with the severity of the actual sanction $(S){ }^{9}$

$$
\mathrm{ES}=p \times S
$$

Based on this deterrence hypothesis, the rich and abundant literature on economics of crime and law enforcement suggests that potential offenders respond to the incentives created by the criminal justice system and crime rates hence inter alia depend on risks and benefits of crime. ${ }^{10}$ The goal of policy making according to the economic framework is to induce compliance at lowest cost. Assuming that potential criminals are rational utility maximisers who base their decisions to commit or not to commit a crime on an expected utility calculation, they will comply with the law as long as the benefits of compliance outweigh the costs of compliance. As such, polluters are expected to comply with environmental regulations if the probability of being apprehended and sanctioned coupled with the penalty imposed will be sufficiently high. Even though the reality shows that enforcement tends to be rather low in terms of the number of sanctions imposed, ${ }^{11}$ large numbers of companies nevertheless comply. This phenomenon is in the literature referred to as the "Harrington paradox.. ${ }^{2}$ Many violations are also settled out of court, or there is an agreement made not to impose a sanction for return to compliance. ${ }^{13}$ In addition, in some cases no sanction is imposed because the violation took place out of ignorance. In those cases, education may prove more effective than sanctioning. ${ }^{14}$ However, this does not render the question of the need for adequate enforcement policies irrelevant.

9 Gary S Becker, 'Crime and Punishment: An Economic Approach' (1968) 76 Journal of Political Economy 169.

10 Nuno Garoupa, 'The Theory of Optimal Law Enforcement' (1997) 11 Journal of Economic Surveys 267.

11 Ogus and Abbot (n 2); Carole M Billiet and Sandra Rousseau, 'Zachte rechtshandhaving in het bestuurlijke handhavingsspoor: de inspectiebeslissing en het voortraject van bestuurlijke sancties. Een rechtseconomische analyse' (Soft law enforcement in the administrative enforcement track: the inspection decision and the preliminary process of administrative sanctions. A law and economics analysis) (2005) 1 Tijdschrift voor Milieurecht (Journal of Environmental Law) 2; Michael G Faure and Katarina Svatikova, 'Enforcement of Environmental Law in the Flemish Region' (2010) 19 European Energy and Environmental Law Review 60.

12 Winston Harrington, 'Enforcement Leverage when Penalties are Restricted' (1988) 37 Journal of Public Economics 29; Anthony Heyes and Neil Rickman, 'Regulatory Dealing - Revisiting the Harrington Paradox' (1999) 72 Journal of Public Economics 361; Robert Innes and Abdoul G Sam, 'Voluntary Pollution Reductions and the Enforcement of Environmental Law: An Empirical Study of the 33/50 Program' (2008) 51 Journal of Law and Economics 271.

13 OECD, Ensuring Environmental Compliance: Trends and Good Practices (OECD Publishing 2009).

14 Bowles, Faure and Garoupa (n 1). 
Policymakers will still have to look at the efficiency and/or cost-effectiveness of the enforcement instruments to protect the environment. Different legal instruments, such as criminal or administrative sanctions, have different enforcement costs as well as a different impact on the behaviour of potential offenders. There are several trade-offs to be made when using these instruments, which will be presented in the following subsection.

\subsection{Administrative versus Criminal Law: General}

Law and Economics scholarship has discussed the trade-offs of using criminal as opposed to administrative law in general, as well as how this applies to the enforcement of environmental law specifically. ${ }^{15}$ Based on this literature, enforcement through criminal law is preferred when the harm to society, or benefit to the offender is significant, the probability of detection is low, and when criminal law can provide additional stigma and/or an educative role (expressive function). In these circumstances, administrative law might not suffice. In addition, enforcement through administrative law could give rise to problems of capture (collusion between the regulator and the regulated) and error costs that are too high (as the standard of proof is much lower than under criminal law). Most importantly, administrative sanctions might be too low to provide sufficient deterrence.

On the other hand, the literature points to the fact that due to the high enforcement costs of the criminal system, administrative sanctioning might be preferred in some instances. These are for example, when the harm is low (hence insolvency is less of a problem), prevention (through licensing and monitoring) is more effective than ex post deterrence (through sanctioning), or if a violation is a matter of inadequate information, which could be solved by providing sufficient information to the offenders. ${ }^{16}$ Due to the lower standard of proof in administrative law, it is likely that more violations will be sanctioned (enforcement is higher), and hence the ex ante probability of sanctioning also increases. Thus, based on this general framework, should environmental law be enforced through administrative or criminal law?

\subsection{Criminal Law to Enforce Environmental Regulations?}

There are only a limited number of empirical studies that have tested the question of which enforcement instruments are adequate to protect the environment. In general, these studies point to a similar conclusion: enforcement of environmental offences through criminal law is relatively low in terms of the 
number of prosecutions relative to the number of established violations. ${ }^{17}$ The main reasons might be the high administrative costs of the criminal justice system (high standard of proof), heavy workload of courts, judges giving priority to 'real crimes' and lacking adequate knowledge to assess environmental harm. As the probability of detection is rather low, coupled with a low sanction and high benefit from undertaking activities that risk environmental harm, according to the Becker model there will be low deterrence. Thus, compliance will follow only if the potential offender is highly risk averse, his subjective perception of the formal sanction is very high, he significantly overestimates the probability of conviction, and he attaches significance to non-legal sanctions coming from a criminal conviction (stigma, loss of reputation). ${ }^{18}$ All these factors increase the ES a violator might be facing.

As an alternative to criminal enforcement, sanctioning through administrative law has been proposed. We support this argument for the following reason: given the high costs of criminal law enforcement, legal systems that only have criminal law enforcement systems and no or limited possibilities to enforce via administrative law may be less effective. The assumption is that given the high costs of the criminal procedure, public prosecutors allocate their scarce resources to the 'most important' cases. As a consequence, the majority of environmental offences might not be prosecuted, while there is a range of cases, which deserve sanctions. By also enforcing via administrative penalties, the probability of imposition of a sanction will be increased, as will the deterrent impact of enforcement.

To the extent that no alternative punitive mechanism (like administrative penalties or fines) exists, ${ }^{19}$ this could lead to under-deterrence since rational Becker-type polluters are facing low expected (formal) sanctions. Administrative fines might be relatively cheaper to impose than criminal sanctions, as the administrative proceedings are less strict and more informal in terms of money, time and personnel. In addition, as an administrative sanction is imposed by the environmental agency itself, there is no need to forward the case to the public prosecutor. Hence if there are enough cases where the gain from enforcement is greater than the administrative enforcement costs (where the cost of pollution is higher than the cost of imposing an administrative sanction), then there is a role for administrative law.

In addition, suspension or revocation of licences could be seen as having incapacitating or preventative effects, and hence, provide a significant deterrent. $^{20}$ Therefore, next to having only a criminal law system in place to enforce

17 Ogus and Abbot (n 2); Billiet and Rousseau (n 11); Faure and Svatikova (n 11).

18 Ogus and Abbot (n 2).

19 The goal of administrative sanctions in general is to stop the harmful activity and repair the damage done. 'Reparatory' sanctions, such as stop notices and orders or suspension or revocation of licences are different from punitive administrative sanctions, such as administrative fines.

20 Ogus and Abbot (n 2). 
environmental regulations, allowing environmental agencies to impose administrative sanctions might be more effective in reducing environmental harm and at a lower cost. By letting environmental agencies handle the less serious cases, which are not worth criminal prosecution, the number of dismissed criminal cases decreases and the overall level of enforcement increases (ex ante). In the following part of the article, four examples of legal systems will be examined and analysed, where two rely on using a single instrument (criminal law) to enforce environmental violations, and the other two rely on the use of a complementary system of criminal and administrative enforcement. Some implications will be drawn as to their ability to induce compliance with environmental regulations.

\section{Experiences in Four Legal Systems}

This section discusses the enforcement instruments in four jurisdictions, where the UK and the Flemish region rely (at that time) primarily on criminal law to enforce environmental regulations, while Germany and the Netherlands rely on both, administrative and criminal law sanctions. The legal systems are briefly sketched and stylised facts based on the available empirical data are formulated.

\subsection{Flemish Region}

The enforcement of environmental law in Belgium has been allocated to regions, and in this article we will be focusing on the Flemish region. ${ }^{21}$ The most important environmental Acts in the Flemish region are the Flemish Decree concerning environmental permits $1985^{22}$ and the Waste Decree concerning the prevention and the management of waste (Afvalstoffendecreet) 1981 (amended by a subsequent Decree of 20 April 1994). The Environmental Inspectorate (Milieu-inspectie or MI) of the Flemish Environmental Ministry has the most important competences to control compliance with environmental regulations. Environmental law in the Flemish region was, until 2009, mainly enforced through criminal law. Only for particular offences (related to manure), could an administrative fine be imposed. Since May 2009, the

21 Sabien Lust, 'Administrative Law in Belgium' in René Seerden and FAM Stroink (eds), Administrative Law of the European Union, its Member States and the United States: A Comparative Analysis (2nd edn, Intersentia 2007) 5-60.

22 Michael G Faure and Gunter Heine, Environmental Criminal Law in the European Union. Documentation of the Main Provisions with Introductions (Max Planck Institute for Foreign and International Criminal Law 2000); K Deketelaere, 'Public Environmental Law in Belgium in General and in the Flemish Region in Particular' in René Seerden, MA Heldeweg and KR Deketelaere (eds), Public Environmental Law in the European Union and the United States: A Comparative Analysis (Kluwer Law International 2002) 33. 
Flemish Environmental Enforcement Decree (Milieuhandhavingsdecreet) 2008 has been in force and gives the regional agency (gewestelijke entiteit) the power to impose administrative fines. Some of the crimes have been declassified as administrative offences (milieuinbreuken), which are no longer subject to criminal law. In that case the (exclusive) administrative sanction is the only sanction available. For crimes, which are still forwarded to the public prosecutor, there is a possibility for the regional agency to impose an (alternative) administrative fine, but only in cases where the prosecutor decides not to prosecute. Together with the administrative fine, another non-criminal sanction can be imposed, which is equal to the benefit obtained from the illegal activity (in Dutch, voordeelontneming or confiscation of illegal gain).

For all crimes, once a violation has been observed, the Environmental Inspectorate (MI) is legally obliged to issue a Notice of Violation (NOV) (in Dutch, process-verbaal $(P V))$ to the public prosecutor. The MI then follows up by formulating a warning, which is submitted to the offender. Once the public prosecutor receives the NOV, he could ask the MI for more information, dismiss the case from any formal consequences, offer a 'transaction' (payment of a sum which will extinguish the criminal prosecution-a 'settlement'), or proceed to prosecute the violator in court. If convicted, a criminal fine or imprisonment could be imposed. All offences are in theory subject to possible imprisonment.

The only source available, and providing at least some 'hard' data, is the yearly enforcement reports of the Environmental Inspectorate (MI). ${ }^{23}$ Data on the enforcement of environmental law in the Flemish Region has been collected by the MI at the level of five Flemish provinces over the period of 16 consecutive years, 1993-2008. The sample used consists of several enforcement variables, all of which can be found in the yearly reports. This study has obtained and used yearly data on the number of inspections, violations, the number of firms inspected and some data on the number of administrative reparatory sanctions and administrative fines. Furthermore, there is quite extensive reporting on what the public prosecutor in each province has done with the violations in each given year (1993-2004), giving us the number of dismissed cases from criminal prosecution, 'transactions', acquittals and convictions (see Tables 1 and 2).

Notwithstanding the limitations of this data (incompleteness, inconsistency), some facts can be formulated. First, with regard to the ex ante (pre-enforcement) inspecting activity of the Environmental Inspectorate (MI), there are on average 12,125.3 inspections performed and on average 4,786.9 firms inspected per year. As the number of inspections is more than twice the number of firms inspected, at least some firms get inspected more than once.

23 Department of the Environmental Inspectorate, the Flemish Region (Afdeling Milieu-inspectie), Environmental Enforcement Reports (Milieuhandhavingsrapporten) (1993-2008). 


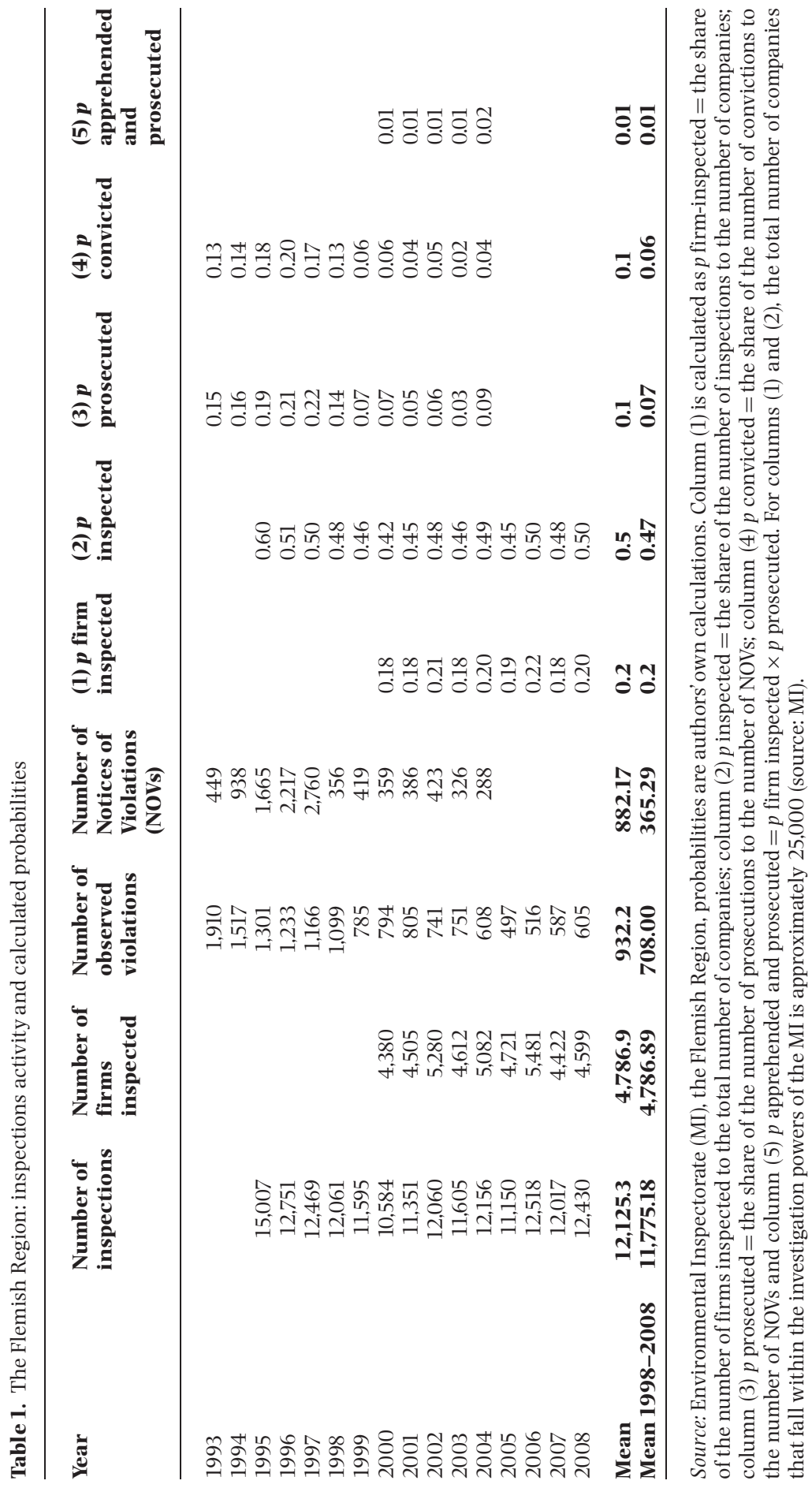


Table 2. The Flemish Region: follow up on violations (percentage of total number of NOVs in a given year)

\begin{tabular}{|c|c|c|c|c|c|}
\hline Year & $\begin{array}{l}\text { Dismissal, } \\
\text { n (\%) }\end{array}$ & $\begin{array}{l}\text { Transaction, } \\
\text { n (\%) }\end{array}$ & $\begin{array}{l}\text { Acquittal, } \\
\text { n (\%) }\end{array}$ & $\begin{array}{l}\text { Conviction, } \\
\text { n (\%) }\end{array}$ & $\begin{array}{l}\text { Total } \\
\text { NOVs }\end{array}$ \\
\hline 1993 & $265(59)$ & $115(26)$ & $11(2.45)$ & $58(12.92)$ & 449 \\
\hline 1994 & $589(63)$ & $201(21)$ & $13(1.39)$ & 135 (14.39) & 938 \\
\hline 1995 & $1,007(60)$ & $336(20)$ & 19 (1.14) & $303(18.20)$ & 1,665 \\
\hline 1996 & $1,255(57)$ & $486(22)$ & $40(1.80)$ & 436 (19.67) & 2,217 \\
\hline 1997 & $1,505(54)$ & $659(24)$ & $120(4.35)$ & 476 (17.25) & 2,760 \\
\hline 1998 & $162(45)$ & $144(40)$ & 4 (1.12) & 46 (12.92) & 356 \\
\hline 1999 & $263(63)$ & $126(30)$ & $3(0.72)$ & $27(6.44)$ & 419 \\
\hline 2000 & $241(67)$ & $94(26)$ & $3(0.84)$ & $21(5.85)$ & 359 \\
\hline 2001 & $284(73)$ & $84(22)$ & $1(0.26)$ & $17(4.40)$ & 386 \\
\hline 2002 & $282(67)$ & $117(28)$ & $3(0.71)$ & $21(4.96)$ & 423 \\
\hline 2003 & $225(69)$ & $90(28)$ & $5(1.53)$ & $6(1.84)$ & 326 \\
\hline 2004 & $179(62)$ & $83(29)$ & $14(4.86)$ & $12(4.17)$ & 288 \\
\hline Mean & $521.42(62)$ & $211.25(26)$ & $19.67(1.76)$ & $129.83(10.25)$ & $882.17(100 \%)$ \\
\hline Mean 1998-2004 & $233.71(64)$ & 105.43 (29) & $4.71(1.43)$ & $21.43(5.8)$ & $365.29(100 \%)$ \\
\hline
\end{tabular}

Source: Environmental Inspectorate (MI), the Flemish Region. The table gives the absolute values of the number of dismissals, transactions, acquittals and convictions. The share of each out of total number of violations in \% is presented in brackets. These percentages are authors' calculations. The number of prosecutions has been calculated as the sum of acquittals and convictions.

This might be related to the targeting approach used by MI where firms that are more likely to be offenders are more likely to be inspected than compliant firms. ${ }^{24}$ In addition, sometimes several inspections are needed to determine one violation. On average of these 12,125.3 inspections per year (on average) there are 932.2 violations detected (per year), meaning in around $8 \%$ of the performed inspections a violation is observed (in this article referred to as the 'observed violations ratio'). ${ }^{25}$ From Table 1 it can be seen that the number of observed violations dropped considerably (from 1,910 in 1993 to 605 in 2008), while the number of inspections and the number of firms inspected remained relatively constant. To suggest that the enforcement is working would be too strong an inference for two reasons: (1) we do not know the 'hidden' number of violations - ie those that go undetected; and (2) the calculation of violations before 1998 differed across the provinces, which might have resulted in an overstatement of the number of observed violations (some provinces counted a violation and its subsequent 'follow-up' violations as a single violation, while other provinces classified these as separate). Once a violation is observed, the MI is legally obliged to issue a NOV. There are on average 882 NOVs per year

24 Sandra Rousseau, 'Timing of Environmental Inspections: Survival of the Compliant' (2007) 32 Journal of Regulatory Economics 17.

25 It should be noted that the calculation of violations has been unified only since 1998, and hence the numbers for years before 1998 might overstate the average number of violations. In other words, there would be less than $8 \%$ of inspections resulting in a violation. 
dealt with by the public prosecutor's office in the entire Flemish Region. ${ }^{26}$ To correct for the non-unified classification of violations of pre-1998, average values have also been calculated for the period 1998-2008. In doing so, we have decreased the number of observations; however, the consistency of data is strengthened. It now shows that there are on average only 708 observed violations per year, which leads to around $6 \%$ of inspections where a violation has been observed, and only 365 NOVs on average per year reported by the public prosecutor. ${ }^{27}$ It should be noted that a NOV could also arrive at the public prosecutor from the police forces and from other administrations. However, the statistics reported here are only from the MI.

It is more interesting, however, to look at the probabilities that a violation will be detected and prosecuted. ${ }^{28}$ As explained in Section 2, a 'rational' company will value the costs and benefits of compliance when making a decision whether to comply or not. The probability of being apprehended and prosecuted $(p)$ is one of the two factors determining the level of the ES $(\mathrm{ES}=p \times S)$. From our collected data, we computed the probability that a firm will be inspected, defined as the ratio of the number of firms inspected to the total number of companies. There are approximately 25,000 companies that fall within the investigation powers of the $\mathrm{MI}^{29}$ and as mentioned above, on average 47,869 companies are inspected per year. This leads to a probability of 0.2 that a company will be inspected, on average, which could be considered as low. ${ }^{30}$

Furthermore, the (conditional) probability of being prosecuted has been computed based on the number of prosecutions out of the number of NOVs dealt with by the public prosecutor ( $p$ prosecuted) (data on the number of prosecutions in Table 2). On average, this probability is 0.1. For the period 19982008 , this probability of prosecution is only $0.07(7 \%)$. This suggests that even if a company is detected committing a violation and a NOV is issued, 9 out of 10 times it will not be brought to court-ie prosecuted. This implies that to see the real probability that a company will actually be penalised for a

26 The number of NOVs presented in the tables corresponds to the number of NOVs dealt with in a given year by the prosecution office. However, some of these NOVs are not necessarily issued in that given year but could have been issued in a previous year.

27 This is less than half if we disregard the pre-1998 period, which might be due to the differences in reporting pre- and after 1998, or because over years the prosecutor's offices report less and less.

28 It should be noted here that the probabilities of detection relate only to the observed violations and thus it is a conditional probability upon a violation being found. We cannot put a number on the amount of unobserved violations, which implies that the resulting probabilities of being detected are systematically lower than what we report.

29 Environmental Inspectorate, the Flemish Region, personal interview.

30 Calculating the probability of being inspected disregarding the number of companies inspected (defined as the ratio of the number of inspections to the total number of companies) would greatly overestimate this parameter. According to our computations this would result in a probability of 0.5 , which would mean every second company is inspected, which is not true. 
violation, we must account not only for the probability of being inspected (and hence incur a high chance of being found in violation, assuming a violation was committed), but also for the probability of being prosecuted once a violation has been established. It is a fact that not all violations are found and those that are found are not all prosecuted. Thus, the probability of being apprehended and prosecuted for a violation is defined as the product of the probability that a firm will be inspected (assuming if a firm is in violation and an inspection takes place, the violation will be detected) and the probability it will be prosecuted. On average this probability is less than 0.01 -ie less than $1 \%$, meaning only one in a hundred firms that are in violation will be detected and prosecuted (based on this data). The probability of being convicted, which is also important as not all prosecutions lead to convictions, is according to our data on average the same as the probability of being prosecuted. This indicates that once a case is prosecuted, there is a very high chance that the wrongdoer will be convicted. Thus, the public prosecutor seems to select cases according to their chances of winning against the wrongdoer.

When looking at the post-detection enforcement once the MI observes a violation, in addition to sending a NOV to the public prosecutor, the MI could use a soft approach and issue a recommendation or a warning, or impose administrative sanctions and measures, and in case of violations of the regulations concerning manure, administrative fines. Once a NOV is sent to the public prosecutor, he can dismiss the case, issue a transaction or prosecute. The use of these options in absolute numbers as well as in relative terms is shown in Table $2^{31}$

Taking into consideration only the period 1998-2004, since from 1998 the system was unified across provinces, as mentioned earlier, there are on average 365 NOVs in total per year (1998-2004). Furthermore, it shows that on average there are $64 \%$ of criminal cases dismissed from prosecution, $29 \%$ transactions, $5.8 \%$ convictions and $1.43 \%$ acquittals per year. Thus on average, around $7 \%$ of NOVs are prosecuted, which might not provide sufficient incentive ex ante to comply with the environmental regulations in the first place.

With regard to the level of fines imposed, although MI does not provide data on the size of penalties imposed, some estimates can be found in the literature. Billiet and Rousseau find an average criminal fine of $€ 5,000$ imposed both in

31 The absolute numbers are comparable only from 1998 when the reporting system for violations was unified, and there seem to be three outliers, namely years 1995-97. Therefore, the values are also reported in relative terms (in brackets) as a percentage of the total number of official reports issued in a given year, and hence made more comparable assuming that in a given year the ratios of dismissals and convictions were not affected by the differences in classifying violations across provinces. Average values are also calculated only for the period 1998-2004 to give more reliable estimates. In addition, the data on the follow up might be biased due to the fact that it is based on the voluntary reporting of the public prosecutors' offices. There is a variation in this reporting across offices. 
the court of first instance as well as in appeal for Gent region in the period 1990-2000. ${ }^{32}$ In case of transactions (settlement with the public prosecutor), the average payment sum was only $€ 260$. $^{33}$ These average fines have recently been slightly increased. ${ }^{34}$ In the period 2003/2004-07 in Gent (in the criminal procedure) and in Brussels (in the administrative procedure), ${ }^{35}$ the average criminal fine for legal persons was $€ 14,569$ at First Instance and $€ 10,733$ on Appeal. For natural persons, the average criminal fine was $€ 3,787$ at First Instance and $€ 7,061$ on Appeal. With regard to the length of imprisonment, the majority of prison terms (circa 90\%) does not last longer than 6 months. The problem is that usually very short prison sentences are not executed. As a result of this, effectively no sanction is executed. In the administrative track, the average administrative fine for legal persons is $€ 4,477$ at First Instance ( $€ 672$ for natural persons) and $€ 11,276$ on Appeal ( $€ 1,121$ for natural persons). What can be implied from these results is that on average fines are rather low in comparison to the benefits these violators might gain by violating the law, notwithstanding the rather low probability of detection and sanctioning. Unfortunately, we do not have data on the number of prison sentences.

\subsection{England and Wales}

The Environmental Permitting (England and Wales) Regulations $2010^{36}$ are one of the key pieces of environmental legislation in England and Wales. These, inter alia, streamline permitting provisions for waste and pollution prevention and control. The enforcement lies in the hands of the Environment Agency (EA). In the UK in the 1980s, environmental agencies used mainly "informal' compliance strategies, such as persuasion and verbal warnings to achieve compliance. ${ }^{37}$ Until the end of 2008, environmental law was primarily underpinned through more 'formal' criminal law, where the EA could prosecute before a criminal court for criminal sanctions, including fines and imprisonment for violations, as well as a formal caution or issue of a warning. ${ }^{38}$

32 Carole M Billiet and Sandra Rousseau, 'De hoogte van strafrechtelijke boetes. Een rechtseconomische analyse van de milieurechtspraak (1990-2000) van het Hof van Beroep te Gent' (The size of criminal fines. A law and economics analysis of the environmental criminal justice (1990-2000) of the Court of Appeal in Gent) (2003) 2 Tijdschrift voor Milieurecht 120.

33 Billiet and Rousseau (n 11).

34 Carole M Billiet and others, 'Milieucriminaliteit: feiten omtrent bestraffing' (Environmental crime: facts about punishment) (2009) 3 Panopticon 69; Carole M Billiet and others, "Milieucriminaliteit in handen van strafrechters en beboetingsambtenaren: feiten uit Vlaanderen en Brussel' (2009) 36 Milieu \& Recht 342.

35 In the Brussels region, administrative fines already existed before 2009, unlike in the Flemish Region. This allows for the comparison of the criminal track with the administrative track in the former.

36 Environmental Permitting (England and Wales) Regulations 2010, SI 2010/675 (EPR 2010).

37 Carolyn Abbot, Enforcing Pollution Control Regulation: Strengthening Sanctions and Improving Deterrence (Hart Publishing 2009).

38 ibid; Environment Agency, Enforcement and Prosecution Policy (2008), s 8 (EA EPP 2008). 
In England and Wales, the environmental agency can take on the role of prosecutors, unlike in some other legal systems, where the prosecution is separate from administrative agencies. ${ }^{39}$ In addition, the enforcing authority can use administrative tools such as powers of suspension and revocation of environmental licences, issue enforcement or prohibition notice or carry out remedial works. ${ }^{40}$ However, in the UK the system of administrative fines to enforce environmental regulations was limited.

This changed with the introduction of the Regulatory Enforcement and Sanctions Act 2008, ${ }^{41}$ which entered into force on 1 October 2008. This Act gave some regulatory bodies, including the EA, the power to impose a greater repertoire of civil (administrative) sanctions. These administrative sanctions are introduced by the Environmental Civil Sanctions Order $2010^{42}$ and the Environmental Civil Sanctions (Miscellaneous Amendments) Regulations 2010. ${ }^{43}$ The EA Enforcement and Prosecution Policy $2008^{44}$ is replaced by the Enforcement and Sanctions Statement $2011^{45}$ and by the Enforcement and Sanctions Guidance 2011. ${ }^{46}$ Besides other administrative powers, the EA is enabled with two types of administrative fines - the fixed monetary penalty (FMP), and the variable monetary penalty (VMP). In both cases, a criminal standard of proof ('proof beyond a reasonable doubt') must be applied if the fine is appealed. Hence administrative fines might still be easier to implement (at least if not appealed), but in these cases not because of a lesser standard of proof, as discussed in the introduction. The FMP is similar to the Flemish exclusive administrative fine, as it is a rather low level fine imposed for minor offences, such as the failure to monitor. The VMP bears similarities with the Flemish alternative administrative fine, as it is applied to moderate to serious offences. ${ }^{47}$ However, the main difference is that these sanctions do not aim to replace a criminal sanction (as in Flanders), but to fill the gap in enforcement where prosecution does not seem to be in the public interest. This might be the case because in England and Wales, the EA acts also as a prosecutor rather than merely as an administrative body in the strict sense. That is also why the imposition of the VMP is decided by the EA, and does not depend first on the decision of the public prosecutor to prosecute or not, as is the

In Scotland and Northern Ireland the relevant environment agencies cannot undertake their own prosecutions but must also refer to public prosecutors.

40 EPR 2010 (n 36); EA EPP 2008 (n 38) s 7.

41 Regulatory Enforcement and Sanctions Act 2008 (Commencement No 2) Order 2009, SI $2009 / 550$.

42 Environmental Civil Sanctions (England) Order 2010, SI 2010/1157.

43 Environmental Sanctions (Misc. Amendments) (England) Regulations 2010, SI 2010/1151.

44 EA EPP 2008 (n 38).

45 Environment Agency, Enforcement and Sanctions Statement (2011).

46 Environment Agency, Enforcement and Sanctions Guidance (2011).

47 Offence is defined as a breach of legislation. There is no particular classification into criminal or administrative offence. 
case in Flanders. Thus, administrative fines in England and Wales were introduced to provide flexibility and proportionality (intermediate sanctions) to the regulator, in this case to the EA. ${ }^{48}$ As in Flanders, the aim of these fines can be seen as one of deterring and removing the financial benefit from the violator. Guidance to regulators on how to apply these administrative sanctions is provided by the Department for Environment, Food and Rural Affairs (DEFRA). ${ }^{49}$

Stigma and reputation is likely to be a concern for the businesses, as the EA publishes in their Spotlight reports which companies perform well in terms of environmental protection, and which have been prosecuted for environmental offences. $^{50}$

Published environmental enforcement data in England and Wales is somewhat scarce and inconsistent. The EA provides some data in their Annual Report and Accounts. However, only the latest report is available on their website. ${ }^{51}$ Nevertheless, it is possible to get limited data going back 5 years from the EA's Spotlight Reports. ${ }^{52}$ These 'Spotlight' reports, published by the EA, report on the performance (good or bad) of business and create a so-called 'naming and shaming' effect. In addition, the House of Lords Written Answers $^{53}$ provides some enforcement statistics, as do the Environmental Data Services (ENDS) report ${ }^{54}$ and the reports of DEFRA. ${ }^{55}$

Data for the period 2000-07 is available from various sources (see Tables 3 and 4). It shows that on average there were approximately 27,925 pollution incidents per year in total (Categories 1-4), ${ }^{56}$ out of which 1,216 on average were serious (Categories 1 and 2 incidents). According to Bell and McGillivray, there are around 25,000 plus pollution incidents (Categories 1-4) per year, resulting in less than $5 \%$ prosecution rate. ${ }^{57}$ Thus, our data points to a similar estimate, with a prosecution rate of around 3\%. However, as the EA states in its Enforcement and Prosecution Policy, only serious incidents with sufficient evidence and public interest will be pursued. As can be seen from Table 4,

48 For example, a review that led to the new system showed that regulators felt that magistrates did not fully understand the gravity of breaches and that a criminal response was not always appropriate - eg if a respectable company had made a mistake for which it had to bear serious consequences. Introduction of alternative sanctions was designed to provide the system with more flexibility and proportionality with regard to sanctioning.

49 DEFRA, Civil Sanctions For Environmental Offences: Guidance To Regulators In England On How The Civil Sanctions Should Be Applied, And Draft Guidance For Wales (2010).

50 Environment Agency, Spotlight Reports (2004-2008).

51 Environment Agency, Annual Report and Accounts (2007-2008).

52 EA (n 50).

53 HL Deb 6 February 2008, vol 698, col WA193.

54 ENDS, 'Agency to Target 'Big, Bad and Nasty' Crime' (May 2005) 364 ENDS Report 14-15.

55 DEFRA, Effectiveness of Enforcement of Environmental Legislation (2006); DEFRA, Trends in Environmental Sentencing in England and Wales (2003).

56 Category 1 incidents (persistent and extensive effects), Category 2 incidents (significant effect), Category 3 (minimal effect) and Category 4 (no effect).

57 Stuart Bell and Donald McGillivray, Environmental Law (6th edn, OUP 2005). 


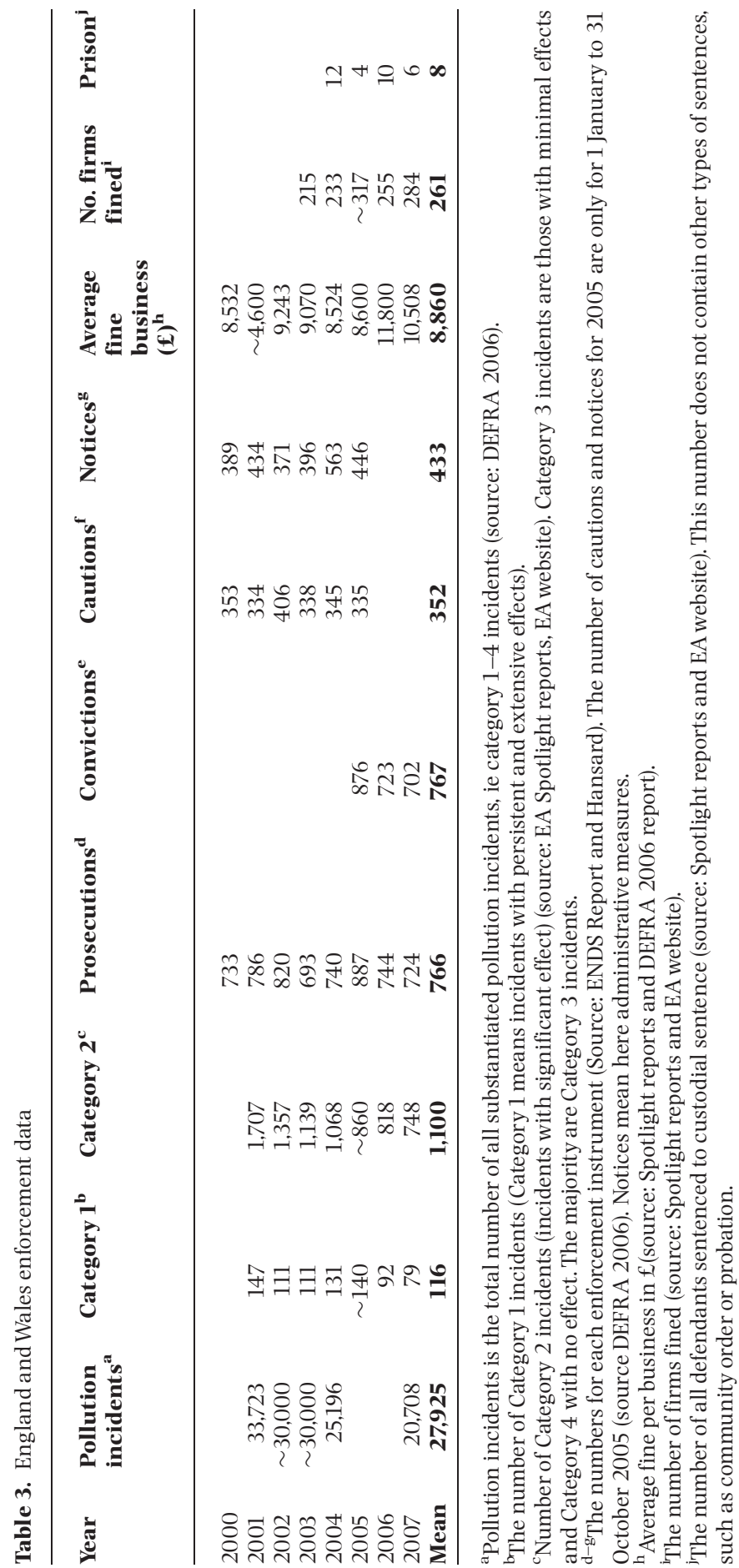


Table 4. England and Wales: prosecution rates, cautions rate and notices rate

\begin{tabular}{lllll}
\hline Year & $\begin{array}{l}\text { Prosecution } \\
\text { rate } \\
\text { (all incidents) } \\
\mathbf{( \% )}\end{array}$ & $\begin{array}{l}\text { Prosecution } \\
\text { rate } \\
\text { category } \\
\mathbf{1 + 2}(\mathbf{\%})\end{array}$ & $\begin{array}{l}\text { Cautions } \\
\text { rate } \\
\text { (all incidents) } \\
\mathbf{( \% )}\end{array}$ & $\begin{array}{l}\text { Notices } \\
\text { rate } \\
\text { (all incidents) } \\
\mathbf{( \% )}\end{array}$ \\
\hline 2000 & & & & \\
2001 & 2 & 42 & 1.0 & 1.3 \\
2002 & 3 & 56 & 1.4 & 1.2 \\
2003 & 2 & 55 & 1.1 & 1.3 \\
2004 & 3 & 62 & 1.4 & 2.2 \\
2005 & & 89 & & \\
2006 & 3 & 82 & & $\mathbf{1 . 6}$ \\
2007 & 3 & 88 & $\mathbf{1 . 3}$ & \\
\hline
\end{tabular}

Source: Authors' calculations based on the available data.

Categories 1 and 2 have a relatively high prosecution rate (increasing over time).

Our data indicates that serious incidents (Categories 1 and 2) have on average a $63 \%$ prosecution rate. This implies that the EA uses targeting. ${ }^{58}$ Cautions have been given only in $1.3 \%$ of all pollution incidents, and administrative tools, such as notices in $1.6 \%$ of all pollution incidents, on average. It should be noted that enforcement notices are more widely used by local authorities for environmental enforcement than by the $\mathrm{EA},{ }^{59}$ hence the notices rate that we calculated might be underestimated. As to the number of suspended or revoked licences, we do not have supporting data; however, this number is expected to be very low. ${ }^{60}$ The percentages of any formal action by the EA seem to be very low, which in turn indicates a very high rate of non-prosecution. This might also have to do with the fact that due to the type of harm specific to environmental offences (diffuse, remote), it is not always easy to identify the offender. ${ }^{61}$ This poses serious problems for the Agency to collect sufficient evidence in order to initiate a prosecution. Similar problems related to prosecution are present in all jurisdictions but could be to a certain extent mitigated if the jurisdiction provides for administrative fines.

As to criminal fines and prison sentences, the average fine per business imposed by the courts is $£ 8,860$. This still seems to be relatively low compared to the benefits of violation, which might amount to tens or hundreds of

58 Heyes and Rickman (n 12).

59 DEFRA, Review of Enforcement in Environmental Regulation: Report of Conclusions (2006).

60 Ogus and Abbot (n 2) show that between 1996 and February 2001, there have been only six waste management licences revoked, and that the EA is using this tool as a last resort.

61 The ENDS Report (n 54) states that in 2004 offenders were identified only in $61 \%$ of major incidents. 
thousands of pounds. ${ }^{62}$ The reason for this has been suggested to be the fact that judges do not know how to evaluate environmental harm properly, and hence underestimate the level of sanctions needed to deter. ${ }^{63}$ This might also change with the new regulations, as a part of the administrative fine will involve the removal of the financial benefit. The limited data on the number of defendants sentenced to imprisonment indicates on average eight defendants sentenced in this way, which is extremely low given the number of pollution incidents and the number of prosecutions. Factors that may go some way towards explaining this include the fact that custodial sentences are extremely expensive, require strict procedural safeguards, cannot be imposed upon legal entities (firms) and that it is difficult to identify senior management personnel within companies who could be held liable. Unfortunately we do not have data on the length of imprisonment.

\subsection{The Netherlands}

In the Netherlands, environmental law is enforced through a mix of administrative and criminal law. ${ }^{64}$ The main environmental act in the Netherlands is the Environmental Management Act ('Wet milieubeheer') 1993. ${ }^{65}$ This Act integrates a number of previously existing laws in order to increase the transparency of the licensing system. ${ }^{66}$ Chapter 18 of this Act deals with enforcement. Administrative enforcement as a whole is regulated via the General Administrative Law Act 1994 ('Algemene Wet Bestuursrecht' or AWB). Criminal law enforcement is regulated via the Dutch Criminal Code ('Wetboek van Strafrecht') 1881 and via the Economic Offences Act ('Wet Economische Delicten' or Wed) 1997.

As a result, there is a wide variety of sanctions available in the Netherlands: the AWB offers the possibility of imposing administrative sanctions-more particularly an administrative order under penalty or an order stating that an illegal activity has to be rectified; administrative fines are not available in the Netherlands for violations of environmental laws. In general criminal law (the Dutch Criminal Code), the most common sanctions are the criminal fine and imprisonment (and an increasing use is also made of the removal of illegal gains). Finally, the Wed still offers additional sanctions such as the publication of the judgment or the closure of a company. This therefore leads to quite a

62 For some examples of inadequate sentencing, see EA Spotlight Reports ( $\mathrm{n}$ 50) and DEFRA 2006 (n 59).

63 R Navarro and D Stott, 'A Brief Comment: Sanctions for Pollution' (2002) 14 Journal of Environmental Law 283; Michael Watson, 'The Use of Criminal and Civil Penalties to Protect the Environment: A Comparative Study' (2006) 15 European Environmental Law Review 111.

64 Civil law plays a role as well, but we do not discuss that within the scope of our article.

65 René Seerden and MA Heldeweg, 'Public Environmental Law in the Netherlands' in Seerden and others (n 22) 382.

66 Faure and Heine (n 22). 
diversified picture. Of course, we have merely addressed the distinction between administrative sanctions (mostly fines) and criminal sanctions from the perspective of operational efficiency. Other, perhaps equally important, aspects could also be included, such as the fact that criminal law has a stigmatic, punitive quality that can be diminished by overuse. Moreover, industries often breach rules unintentionally; this may require a sanction but not necessarily a criminal one.

In practice, when criminal law is used, most of the environmental laws in the Netherlands are enforced through the Wed. In principle, the environmental offences falling under the Wed have a feature of 'abstract' endangerment offence. This means that criminal liability occurs for violations of administrative duties specified in the laws falling under Article 1 of the Wed. An emission or environmental pollution is not required; the abstract danger to the environment (for example operating a plant without a licence) suffices for criminal liability. Article 2 of the Wed specifies, whether the offences under Article 1 are crimes ('misdrijven') or violations ('overtredingen'). Based on this, a corresponding sanction or a measure is applied (Articles 6-8 of the Wed).

On the other hand, the two articles of the Dutch Criminal Code, which are directly related to environmental pollution, Articles 173a and 173b, are an example of a 'concrete' endangerment offence. They read that criminal liability is invoked when a discharge occurs into the water, the soil or the air, and which has been done intentionally (or negligently), and unlawfully. This unlawful discharge is considered to create a concrete endangerment of the environment. However, criminal sanctions are applied only if this discharge threatens public health or someone's life; hence this provision is directed more towards the protection of humans rather than of the environment, and when this has been done unlawfully. ${ }^{67}$ The unlawfulness criterion constitutes a problem since most discharges take place lawfully within the scope of the different regulations. ${ }^{68}$ As a result, these two articles are not widely applied in practice.

The difference between the three 'enforcement' instruments lies also in the type of sanctions available. The AWB offers a wide variety of sanctioning possibilities. A first possibility for the competent administrative body is to issue an administrative order under penalty. ${ }^{69}$ The idea of this competence is to force a perpetrator to comply: the offender has to pay the sum only if he remains unwilling to end the violation in accordance with the administrative order issued by the authorities. ${ }^{70}$ This administrative order should not be confused with the sanction of issuing an administrative fine (in Dutch referred to as

67 ibid 237; GA Biezeveld, 'Rol van het Strafrecht bij de Bescherming van het Milieu' (2009) 3 ELSA Leiden Magazine 19.

68 Faure and Heine (n 22).

69 In Dutch referred to as a dwangsom. The formal competence can be found in art 5:32 of the General Administrative Law Act (Algemene Wet Bestuursrecht).

70 Seerden and Heldeweg (n 65) 382. 
bestuurlijke boete). The aim of an administrative fine is not primarily to end the offence, but to punish the offender. Thus far, the imposition of an administrative fine in environmental law is not possible in the Netherlands (though it is used, for example, in social security legislation) but, like in the Flemish Region and in England and Wales, proposals have been formulated to introduce such fines in the Netherlands as well. ${ }^{71}$ Yet another possibility for the administrative authority is to issue an administrative act stating that the illegal activity has to be rectified (referred to as bestuursdwang). This can lead (for example) to a shutting down of an establishment. ${ }^{72}$ In the majority of cases $(80 \%)$, it is reported that no formal action (in the sense of the imposition of a deterrent sanction) is taken, as many companies are forced into compliance via other measures, such as administrative orders under penalty. ${ }^{73}$ Serious violations are usually prosecuted in parallel with administrative actions, and the prosecutor may also suggest a 'transaction' (settlement). ${ }^{74}$

The Wed offers a larger choice of sanctions than the Dutch Criminal Code, including reparatory sanctions for environmental offences, publication of the judgment imposing sanctions for environmental violations or the closure of the company (available only under the Wed, Articles 7 and 8). The size of the penalty depends on whether the offence is considered a crime or only an infringement of law, and whether it was committed by a legal or natural person. Under the Wed, a fine can be imposed in addition to a prison sentence. Under the Criminal Code, all offences are regarded as crimes and therefore the available sanctions are usually fines and imprisonment. Under Dutch law, the confiscation of an illegal gain is also possible. This increases the total size of the sanction even further.

In the Netherlands, the legal status of the Wed and the AWB is equal and they are used side-by-side. Hence, the argument that criminal law is used as ultimum remedium does not hold in the Netherlands. ${ }^{75}$ Once a violation is observed, the criminal and administrative enforcement bodies negotiate together the allocation of tasks. Generally speaking, violations can be divided according to three categories. ${ }^{76}$ First, environmental violations without criminally relevant circumstances (simple or minor violations) are addressed by the administrative body by imposing an administrative warning, measure or an administrative fine. Second, environmental violations, which the circumstances show to be relevant for criminal enforcement, and are priority enforcement problems, require an action by the administrative body and/or by the public prosecutor. In this case, criminal sanctions, as articulated in Articles

71 Seerden and Stroink (n 21).

72 Seerden and Heldeweg (n 65) 382; Seerden and Stroink (n 21).

73 OECD (n 13).

74 ibid.

75 Biezeveld (n 67) 19.

76 ibid 23. 
6-8 of the Wed, can also apply. Lastly, for serious violations, criminal enforcement is used, with the possibility of being complemented by administrative sanctions, such as the revocation or suspension of permits and possibly shutting down of the company.

A problem with the Netherlands is that there is no systematic data for a longer time period that would register the number of violations and the legal consequences (administrative, criminal), nor on the specific sanctions imposed. One source of data is the inspection reports from the Ministry of the Environment (VROM). However, this data is only available for a limited period of time and comes from the yearly reports of the environmental inspectorate in the Netherlands. The data is available only for a period of 8 years (19992007, with the exception of 2001). The data set provides detailed data on the number of inspections of companies, of vehicles and the number of violations observed. It then also provides information on the number of administrative actions taken and the number of times a criminal action was taken (Table 5).

On average $22.8 \%$ of inspections result in a violation being observed. On average in $39.8 \%$ of these observed violations, an administrative action is taken, whereas in only $23.5 \%$ is a NOV issued and hence a criminal prosecutor is involved. However, any conclusions implied from these results should be drawn carefully as the data is available only for 8 years and the results vary greatly across years. Furthermore, 2005 seems to be an outlier as there were 42,321 inspections performed in that year, which is more than 10 times greater in any other year. What can be concluded is the fact that administrative actions are on average used much more than criminal actions (it should be noted that out of the total number of NOVs sent to the criminal prosecutor, only a portion of violations is prosecuted).

\subsection{Germany}

As far as the enforcement of environmental law is concerned a variety of legal instruments is available in Germany. ${ }^{77}$ They can be found either in administrative law (administrative sanctions), in administrative penal law (Ordnungswidrigkeitenrecht) or in 'true' criminal law. ${ }^{78}$ First, administrative agencies in Germany have at their disposal a variety of administrative instruments to force an offender to comply with administrative provisions, such as licence conditions. ${ }^{79}$ A second possibility is the use of the so-called Ordnungswidrigkeitenrecht. ${ }^{80}$ This is a system of administrative penal law,

77 Faure and Heine (n 22).

78 Administrative sanctions have as a goal either to repair harm done (restoration) or to prevent further harm in the future. They usually impose specific behaviour upon the perpetrator and their main goal is restoration or prevention. Administrative penal law on the other hand is of a punitive character and imposes fines on the perpetrator to deter violations.

79 Seerden and Stroink (n 21).

80 Administrative Offences Act (Ordnungswidrigkeitengesetz) 1987, BGBl. I S. 602. 


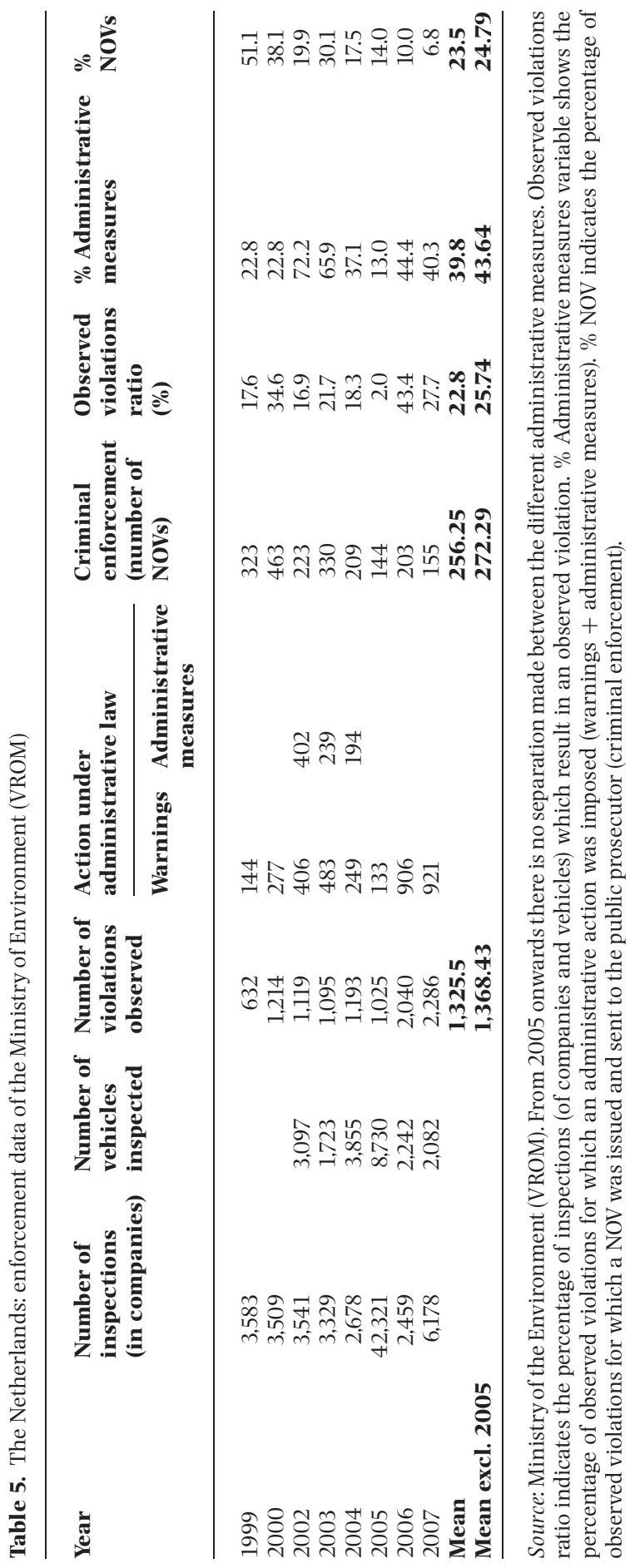


which allows for the imposition of administrative fines (in German referred to as a Geldbuße). The Geldbuße can, on the basis of paragraph 30 of the Ordnungswidrigkeitengesetz, also be imposed against legal persons. ${ }^{81}$ These administrative measures or fines are imposed by administrative agencies and hence without any intervention of the public prosecutor. The third means of enforcement involves criminal offences, which have been incorporated into the German Criminal Code (Strafgesetzbuch) in $1980 .{ }^{82}$ The Criminal Code contains inter alia provisions against water pollution, pollution of the soil and air pollution. ${ }^{83}$ The enforcement of environmental crime in Germany thus principally takes place via these provisions in the Criminal Code. For less serious offences (usually when no emission took place, but only administrative provisions were violated), the administrative penal law will be applied and this can lead to the imposition of an administrative fine.

In the 1980s and 1990s, a group of criminal lawyers and criminologists from the Max Planck Institute for Foreign and International Criminal Law was engaged in a project on the protection of the environment through the use of criminal law. Günter Heine and Volker Meinberg have some relevant data on enforcement of environmental law for the period $1975-86 .{ }^{84}$ It is striking according to these scholars that in 1985 more than $40 \%$ of all criminal cases were not prosecuted. ${ }^{85}$ The numbers presented by Heine and Meinberg were based on a more detailed study carried out by Meinberg published in $1988 .{ }^{86}$

In German criminal procedure (Strafprozeßordnung ${ }^{87}$ or StPO), prosecution of all violations is (formally) the rule. ${ }^{88}$ Hence the StPO contains numerous specific rules and conditions under which it can be decided not to prosecute a case. According to Meinberg's study of $1988,47.5 \%$ of the cases end with a decision not to prosecute by the public prosecutor when there is no reason for

81 Code of Criminal Procedure the German Court of Criminal Procedure (Strafprozessordnung) 1987, BGBl. I S 1074, ber, S 1.319. This is important since the real criminal law in Germany cannot be applied against legal persons. Since the Geldbuße is, however, not considered a criminal sanction, the application of the Geldbuße against firms is accepted.

82 German Criminal Code (Strafgesetzbuch) 1872.

83 M Rodi, 'Public Environmental Law in Germany' in Seerden and others (n 21) 242-243.

84 Gunter Heine and Volker Meinberg, Empfehlen sich Änderungen im strafrechtlichen Umweltschutz, insbesondere mit dem Verwaltungsrecht? (Are changes in environmental criminal law necessary, especially in its relation to administrative law?) (Beck 1988).

85 Although one has to be somewhat careful with interpreting this result: the German term Einstellung (dismissal) does not necessarily imply that nothing took place; in some cases a dismissal is conditional upon the payment of a sum of money.

86 Volker Meinberg, 'Empirische Erkenntnisse zum Vollzug des Umweltstrafrechts' (Empirical observations on the enforcement of environmental law) (1988) 100 Zeitschrift fur die gesamte Strafrechtwissenschaft 112.

87 Code of Criminal Procedure the German Court of Criminal Procedure (Strafprozessordnung) 1987, BGBl. I S. 1074, ber, S. 1.319.

88 This follows from paragraph $\S 152$ II of the German Court of Criminal Procedure (Strafprozessordnung (StPO)). 
public prosecution (hence for policy reasons) on the basis of section 170 II StPO. ${ }^{89}$ Non-prosecution in case of minor offences amounted to $14.6 \%$ of the cases (section 153 I StPO) and 13.1\% were not prosecuted provided that specific conditions were met (section 153a I StPO). Altogether, the result was that $75 \%$ of cases were not prosecuted by the public prosecutor. ${ }^{90}$ With regard to decisions by the courts, Meinberg finds these results remarkable: already a very small number of environmental cases are brought before the criminal court and yet more than $50 \%$ of all cases will be dismissed by the court on the basis of section 153 II (dismiss the case after approval of the public prosecutor) or 153a II (conditional dismissal) of the Code of Criminal Procedure $(16.4 \%+$ $37.2 \%$ ). This basically means that they are not considered as worthy of a penalty and will thus be excluded from the formal sanctioning procedure. ${ }^{91}$ However, this does not mean that there are no consequences for these acts.

Meinberg also discusses the enforcement through administrative fines (Geldbußen). He notices that it is mostly the less important violations that are handled through administrative fines. It would be exceptional for cases where a significant emission (and thus a concrete danger for the environment) took place to be handled through administrative penal law. ${ }^{92}$ He equally concludes that the procedural costs in this administrative penal law are usually extremely low since this is mostly limited to interviewing the perpetrator. ${ }^{93}$ Meinberg found that most of the procedures in administrative penal law with respect to environmental violations end with a decision to impose an administrative fine (a so-called Bußgeldbescheid). The amount of the sanction is, however, on average lower than what would be imposed through the criminal law. ${ }^{94}$

Wolfram Lutterer and Hans J Hoch undertook some highly interesting empirical research, which resulted in a representative data set for environmental violations in Germany. ${ }^{95}$ They analysed in detail how these violations were dealt with both in criminal law and in administrative law. This research dates from approximately 10 years later than the earlier studies by Heine and Meinberg and was published in 1997. They report on the decisions of the public prosecutor in 1014 cases, which they specifically analysed with respect to environmental crime (Table 6).

89 Meinberg (n 86) 139-143.

90 Here again, the $75 \%$ non-prosecution rate means that very few cases are brought before the court, but not that nothing happens. There can be a conditional dismissal made upon the fulfilment of particular obligations by the perpetrator.

91 Meinberg (n 86) 147. Note, however, as mentioned above, if paragraph $\S 153$ a StPO is applied, the dismissal is conditional upon the offender fulfilling specific duties which can amount to paying a sum of money to the state.

92 Meinberg (n 86) 153.

93 ibid.

94 ibid.

95 Wolfram Lutterer and Hans J Hoch, Rechtliche Steuerung im Umweltbereich (Legal governance in environmental policy) (Max Planck Institute for Foreign and International Criminal Law 1997). 
Table 6. Germany: decisions of the public prosecutor, the courts and administrative authorities

\begin{tabular}{|c|c|c|c|c|c|}
\hline \multirow{2}{*}{$\begin{array}{l}\text { Public prosecutor } \\
\text { Dismissal for lack of } \\
\text { evidence (companies) }\end{array}$} & \multicolumn{2}{|r|}{ Courts } & \multicolumn{3}{|c|}{ Administrative authorities } \\
\hline & $24.9 \%$ & Acquittal & $6.6 \%$ & Dismissal section 46 & $24.0 \%$ \\
\hline $\begin{array}{l}\text { Dismissal for lack of } \\
\text { evidence (individuals) }\end{array}$ & $23.2 \%$ & $\begin{array}{l}\text { Dismissal because of } \\
\text { little interest } \\
\text { (section } 153 \text { II StPO) }\end{array}$ & $16.1 \%$ & $\begin{array}{l}\text { Dismissal according to } \\
\text { section } 47\end{array}$ & $9.0 \%$ \\
\hline $\begin{array}{l}\text { Dismissal because of } \\
\text { small interest of the } \\
\text { case (section } 153 \text { I } \\
\text { StPO) }\end{array}$ & $14.7 \%$ & $\begin{array}{l}\text { Dismissal with condi- } \\
\text { tions (section 153a II } \\
\text { StPO) }\end{array}$ & $37.2 \%$ & A warning & $8 \%$ \\
\hline $\begin{array}{l}\text { Dismissal with condi- } \\
\text { tions (section 153a I } \\
\text { StPO) }\end{array}$ & $13.2 \%$ & Conviction & $30.1 \%$ & Imposition of fine & $53.0 \%$ \\
\hline Imposition of a fine & $16.1 \%$ & Other & $9.9 \%$ & Other & $6 \%$ \\
\hline Prosecution & $7.9 \%$ & & & & \\
\hline
\end{tabular}

Source: Lutterer and Hoch (n 95). Dismissal section 46 are cases when there are some uncertainties with respect to the case. Dismissal according to section 47 are cases where the administrative authority does not hold it necessary to impose a sanction.

What is of course striking from the decisions of the public prosecutor is that in almost $60 \%$ of the cases a dismissal took place, whereas in only $7.9 \%$ of the cases did a prosecution take place. Lutterer and Hoch also analysed data on the procedural decisions within the administrative penal law. It should be noted that warnings were used only in $8 \%$ of the cases. Moreover, a warning can, within administrative penal law in Germany, also take place alongside the imposition of a fine (a so-called Verwarnungsgeld). A fine was imposed in $53 \%$ of the cases by the administrative authorities. This is in sharp contrast with the fine imposed by the public prosecutor, which happened only in $16.1 \%$.

When further comparing administrative penal law and criminal law, the authors conclude that in the case of administrative penal law, in $57 \%$ of all cases some noticeable reaction (which one could equate with a sanction) took place. In the criminal procedure (by which we mean in this case the public prosecutor) this was only in $48.9 \%$ of the cases. In that respect the authors concluded that the administrative penal law has a higher probability of a sanction being imposed than the criminal procedure. ${ }^{96}$ However, the average fines imposed through the criminal system were higher than the average fines imposed through administrative penal law. However, for both cases it is clear that the formal statutory possibilities to impose (much higher) sanctions are rarely used. Lutterer and Hoch therefore conclude that in administrative penal law, sanctions are imposed more often, but that on average they are more severe in the criminal procedure. ${ }^{97}$

96 ibid.

97 ibid. 
More recent data is provided by Almer and Goeschl. ${ }^{98}$ Their data set comprises the period 1995-2005 for 16 individual states in Germany, leading to 152 observations (some states have incomplete reporting). Their analysis suggests that once a potential violation has been detected (and there are many violations that go undetected and unrecorded), in only $59 \%$ of cases is the offender identified, and hence a violation formally established. From this $59 \%$ of identified offenders, only $26.3 \%$ are tried. Thus the probability that an offender is apprehended and prosecuted is even lower (maximum 15.5\%). ${ }^{99}$ However, as we indicated above, even in cases where an identified offender is not prosecuted, this does not mean that no reaction takes place at all. With regard to the type of sanctions imposed, only 3.5\% of convicted offenders are sentenced to imprisonment and $6.4 \%$ have to pay a severe fine, which establishes officially a criminal record. In the remaining $90.1 \%$ of convicted offenders, a less stringent criminal sanction is imposed.

\section{Critical Comparative Analysis and Implications}

The theoretical argument we developed in Section 2 has been that allowing for administrative enforcement of environmental violations in addition to relying only on criminal enforcement could be a cost-effective way to decrease the number of criminal cases dismissed by the prosecutor. Assuming there exists a range of offences, which merit sanctions but not necessarily being prosecuted in criminal law, administrative law might play a bigger role. Hence, criminal and administrative sanctions could serve as complementary instruments especially if the budget is constrained.

The previous section analysed the enforcement systems in two countries (Germany and the Netherlands), which rely on both administrative and criminal enforcement, and two jurisdictions (the UK and the Flemish Region) which (at that time) relied primarily (if not exclusively) on criminal law enforcement.

First, it is clear from the data provided that it is not possible to carry out a direct comparative analysis, examining the relative effectiveness of the enforcement systems in the four legal systems. This is not only the case because of data incompatibility, but also because the four legal systems differ in their administrative and criminal systems. As such, the data is not presented as decisive evidence, but used to support the general line of reasoning as discussed

98 Christian Almer and Timo Goeschl, 'Environmental Crime and Punishment: Empirical Evidence from the German Penal Code' (2010) 86 Land Economics 707.

99 The probability that an offender is apprehended and prosecuted equals the probability that an offender is identified multiplied by the probability he will be tried (prosecuted). Moreover, we do not know the number of undetected violations, which decreases the probability of apprehension even further. 


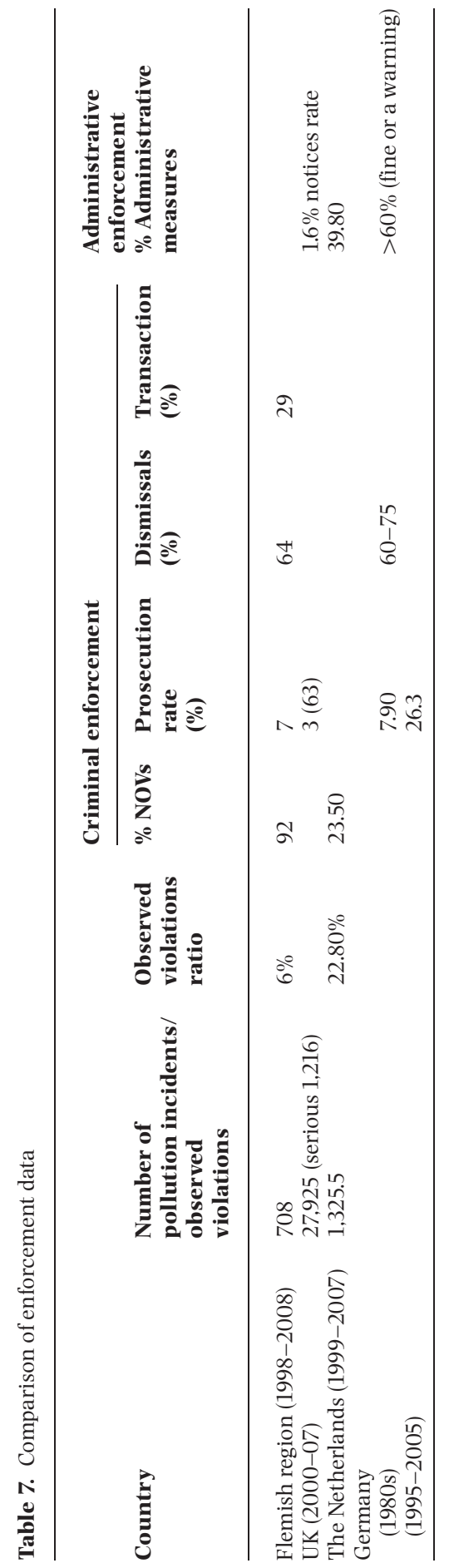


above. We believe that the comparison of the legal systems discussed in our article provides some initial indications to support the hypothesis that administrative sanctions, in the form of fines, could be a valuable additional instrument in the enforcement of environmental violations.

\subsection{A Brief Comparison}

The presentation of the four legal systems made clear that at least on paper, until 2008 the institutional arrangements used were quite divergent. Table 7 presents some comparison between several enforcement variables.

The Flemish Region based the enforcement of environmental law mainly on criminal law. Even though the Environmental Inspectorate issued a NOV for all violations (which was legally obliged), only around $7 \%$ on average were prosecuted. In England and Wales the prosecution rate is even lower-on average $3 \%$ of all pollution incidents. This indicates a very high rate of violations that are not prosecuted. It also indicates a high degree of discretion for the prosecutor in England and Wales. It can be seen that, on average, $63 \%$ of serious violations are prosecuted. This shows that there is a range of offences, which merit enforcement action but do not fulfil the requirements for prosecution. The Flemish Region developed an alternative - a so-called 'transaction' within the criminal law system, and used it for $26-29 \%$ of the NOVs. ${ }^{100}$ In general, what can be observed is a high rate of violations which are not prosecuted and for which no alternative sanctioning mechanism was developed (with the exception of recommendations and warnings, and the 'transaction model' in the Flemish Region), and a rather low level of criminal sanctions compared to the benefits of violations. However, the introduction of administrative fines in both, England and Wales and the Flemish Region indicates that relying only on criminal sanctions also poses a problem for enforcement in practice.

On the other hand, the Netherlands shows a more mixed picture: even though, the Netherlands has no deterring administrative fines for environmental offences, alternatives (like an order under penalty) are often used, as a result of which the perpetrator can be forced to pay a monetary sum. Even though the goal is not deterrence, but to ensure the perpetrator's compliance, in economic terms these administrative orders strongly resemble administrative fines in terms of their deterrent effect. According to the recent estimates of the Ministry of the Environment (VROM), an administrative measure has been imposed on average for around $40 \%$ of violations (approximately half are warnings), while a NOV is issued only on average for $23.5 \%$ of violations. Germany even has a different formal system to deal with administrative offences - the Ordnungswidrigkeitenrecht — which allows the imposition of 
administrative fines. According to our data, warnings (8\%) and administrative fines $(53 \%)$ were imposed in more than $60 \%$ of violations (Table 6). Even though we cannot evaluate properly what happens with the criminal cases that are not brought to court by the public prosecutor in these two countries, the fact that the offender might face, besides criminal, an administrative sanction, increases the level of the ES (under the conditions of sufficiently high probability of being sanctioned and sufficiently high level of the actual administrative sanction imposed) and hence increases the deterrence from an $e x$ ante perspective.

\subsection{Sufficiently High Probability of Sanctions?}

As mentioned above, for all countries examined only a fraction of NOVs are prosecuted criminally, with the tendency of prosecutors towards a focus on the more serious cases, so-called 'targeting' (for example in England and Wales this is evident as $63 \%$ of serious cases are prosecuted). One of the reasons given is the strict evidentiary requirements of criminal proceedings and the costly criminal procedure. Administrative proceedings do not require such stringent requirements, and even if they do (as required under the new regulations in the UK, for example, on appeal), the fact that the violation does not have to proceed to the public prosecutor makes the imposition of administrative sanctions faster and cheaper (disregarding the possibility of appeal). This could imply that the probability of being sanctioned with an administrative penalty strictly outweighs the probability of a criminal sanction. This can also be observed in the Netherlands and Germany.

However, the probability of sanctions being levied also depends on the probability of being detected. This also varies across countries; for example in the Flemish Region the probability of a firm being inspected is 0.2. Hence, the question is not only what is done once a violation is observed, but also how to minimise the 'hidden' number of undetected violations.

In addition, the question arises as to whether one can always interpret the high number of criminal cases that are not brought to court by public prosecutors as cases where 'nothing happened'. First, there could be regulatory dealings $^{101}$ whereby the prosecutor, in cooperation with the environmental agency, leads the violator towards compliance. The dismissal may then fit into an approach of negotiation and persuasion, leading the prosecutor to dismiss only when there is evidence of compliance by the perpetrator. However, the problem remains that even if this soft approach were to lead to compliance ex post, ex ante the average expected (legal) sanction remains low. An interesting alternative for the administrative fine has been developed in the Flemish

101 Paul Fenn and Cento Veljanovski, 'A Positive Economic Theory of Regulatory Enforcement' (1988) 98 The Economic Journal 1055. 
Region (and the Netherlands) in the shape of the proposal of a transaction by the public prosecutor (in 26-29\% of the NOVs). It is a low-cost alternative that avoids the prosecutor having to choose the costly criminal procedure. However, according to the estimates from the literature (with an average payment of about $€ 300$ ), the deterrent effect seems to be very low. Allowing for the imposition of administrative fines seems to be another plausible alternative for dealing with the cases deserving enforcement.

\subsection{Implications for the Actual and ESs}

In a Beckerian world, the ES is a product of the probability of being detected and sanctioned and the actual sanction imposed $(\mathrm{ES}=p \times S)$. The probability of detection and being sanctioned has been discussed above, and it has been implied that administrative sanctioning might increase the probability of being sanctioned as the administrative procedure seems simpler, hence less costly, and the environmental authority is able to impose the administrative sanction by itself. As to the other variable in the equation, the level of the actual sanction, what can be observed from the four countries analysed is the fact that average criminal fines tend to be relatively low. This is the case when compared with both the harm done and the level of the private benefits of violation. In the Flemish Region, earlier research examined average fines imposed by courts and indicated average fines of between $€ 5,000$ and $€ 6,165 .{ }^{102}$ If these were the only costs of the criminal procedure, multiplied with the 0.01 probability of detection and sanctioning, this would lead to ESs varying between $€ 50$ and $€ 61 .{ }^{103}$ Data from England and Wales also leads to low estimates of ESs. We indicated above that average prosecution rates vary between 3 and $5 \%$. An average fine per business imposed by courts is $£ 8.860$, whereas prison sanctions are rarely imposed (Table 3). In Germany, the availability of administrative fines can take away some burden from courts, and as mentioned already, the severity of administrative sanctions might in some cases even outweigh that of criminal sanctions, as courts are not always capable of assessing environmental harm correctly.

It is hence not difficult to argue that, given a fixed budget for enforcement of environmental violations, it might be useful to divide the resources between criminal and administrative law systems, as these may prove to be complementary. Obviously, criminal law offers an incapacitation effect by using imprisonment, which is not available under administrative law. However, there is the

102 Billiet and Rousseau (n 34); Sandra Rousseau, 'Empirical Analysis of Sanctions for Environmental Offenses' (2009) 3 International Review of Environmental and Resource Economics 161.

103 As we will indicate below, there may, however, be other costs involved with the criminal prosecution that could increase the (subjective) ES for the perpetrator. Moreover, to this should also be added the probability that a perpetrator has a transaction imposed by the prosecutor. 
possibility of suspension or revocation of licences, which has been considered to be a strong deterrent with an incapacitation effect, but has rarely been used (for example in England and Wales). Moreover, stigmatic and negative reputational effects might be missing too from administrative law enforcement. Unfortunately, available data does not allow us to further explore non-legal sanctions stemming from a potential criminal conviction. Prosecution before the criminal courts and criminal sanctioning could impose a 'stigma' on firms and thus create reputational loss, which may lead firms towards compliance. $^{104}$ However, environmental agencies can and do (for example in England and Wales) publish a list of companies and their performance, including whether prosecution followed. In addition, even if criminal law does have this additional advantage of creating a stigma or contributing to the creation of social norms, it can barely perform these tasks if it is rarely applied in practice. Moreover, firms might lack information on the actual ES. This has been confirmed in earlier research concerning the Flemish Region, which showed that when firms had to pay a monetary sanction in a first period, the firm was more likely to be in violation in a second period. ${ }^{105}$ Firms that did not have to pay a fine hence overestimated the ES. Sanctioning a violator with too low a fine thus had a perverse learning effect: it informed firms about the low ESs and thus reduced compliance.

\section{Conclusion}

To conclude, it has been argued that administrative sanctioning might be able to deal with a range of violations that do not merit going through the high cost criminal procedure but still merit enforcement at a relatively low cost. Hence, for a range of violations, enforcement through criminal and administrative law would work as substitutes. This would hold under the assumption that enforcement through administrative law is cheaper than through criminal law. Unfortunately, to our knowledge there is no empirical evidence on enforcement costs, and hence we can only reason based upon the difference in costs between the administrative and criminal procedures. Especially for minor violations, administrative fines may be more efficient. If that option does not exist, there is a likelihood that as a result of discretion by the public prosecutor, enforcement agencies would focus the criminal law efforts only on the main cases, not prosecuting many others (such as in England and Wales). But if an alternative through administrative law can be offered, one can

104 J Van Erp, 'Reputational Sanctions in Private and Public Regulation' (2008) 1 Erasmus Law Review 145.

105 Billiet and Rousseau (n 11); Sandra Rousseau, The Impact of Sanctions and Inspections on Firms' Environmental Compliance Decisions (Katholieke Universiteit Leuven, Centrum voor Economische Studiën, Energy, Transport and Environment 2007) 19. 
expect that this takes care of the moderately serious cases deserving enforcement. We looked into four legal systems and examined enforcement practices in two countries with a mainly administrative law enforcement system and two where the criminal law enforcement was the main system. Even though the data is not comparable, our findings as well as the recent legal developments in England and Wales and the Flemish Region seem to confirm this hypothesis. This seems contrary to the current trend in the EU towards the mandatory use of the criminal law to enforce environmental directives.

Our findings basically confirm a statement in earlier literature that whilst criminal prosecution may well be appropriate for the most serious of cases (and therefore must be retained) its deterrent value may be limited due to the fact that the probability of detection, prosecution and conviction can be low. Given a higher probability of imposition, the ES in case of an administrative fine can be higher. This at least calls for a combination of criminal law and administrative fines.

However, one has to be careful with generalising the conclusion that systems that allow for a more balanced use of the criminal law (by combining it with administrative law for minor or moderately serious violations) are more efficient than systems, which merely rely on the criminal law. After all, our data did not allow us to test the overall effectiveness of the differing approaches as far as the effect on environmental quality is concerned, nor on compliance with environmental regulation by firms. Moreover, economic literature has equally indicated that administrative law systems may have the disadvantage that enforcing agencies could enter into a collusive relationship with the regulated firms as a result of which also administrative agencies could not always impose efficient sanctions. ${ }^{106}$ Thus, whenever administrative systems are introduced to deal with environmental crime, some control mechanism to verify the decision-making by administrative authorities (for example by an independent judge or public prosecutor) should be put in place.

Interestingly, it was also noted that in practice there is not always a clear dividing line between administrative and criminal law. Some legal systems using criminal law also levy fines of a more administrative nature since these are payments, which can be imposed by the prosecutor as a low cost alternative to the court system. An example of this approach would be the transaction model used within the Flemish and Dutch systems. They have in fact a more administrative character but are imposed by the public prosecutor. Further research is undoubtedly merited to examine the comparative benefits of these transactions versus fines imposed via administrative law.

Important changes have taken place both in England and Wales as well as in the Flemish Region where enforcement seems to be moving away from

106 This danger may also exist with criminal sanctions where the agency itself is able to bring prosecutions, like in England and Wales. 
criminal law towards administrative sanctions. The data presented in this article merely reflected the situation until 2009 when these changes had not yet come into force. It will be an interesting issue for further research to examine the effects of these recent changes and more particularly whether this led to an increased use of the administrative sanctioning system.

A striking finding during this analysis was that in none of the four legal systems was reliable data available on the number of violations, the consequences attached to those (transaction, administrative penalty, criminal sanction, other), or on the sanction finally imposed. It seems that the trend is to report less and less over time, as the information reported has decreased in more recent years. Even within the countries, the information is only available to a limited extent and for particular time periods and there is no comparability whatsoever between the systems examined. Hence, it is advisable that a harmonised system of data collection on inspections, violations, measures taken and sanctions be established. 